\title{
RESPONSE OF THOMPSON SEEDLESS GRAPEVINES TO APPLICATION OF METHYLENE UREA AND SOME SLOW RELEASE N FERTILIZERS AS APARTIAL REPLACEMENT OF THE FAST RELEASE MINERAL UREA FERTILIZERS \\ Refaai, M.M.
}

Central lab. of Organic Agric. ARC, Giza, Egypt.

E.mail: refaai011@yahoo.com

\begin{abstract}
Thompson Seedless grapevines were fertilized with three slow release fertilizers namely $\mathrm{P}$ and $\mathrm{S}$ coated urea and methylene urea each at $25 \& 50 \%$ of $\mathrm{N}$ as a replacement of the soluble fertilizer urea.

Application of any one of the three slow release $\mathrm{N}$ fertilizers ( $\mathrm{P} \& \mathrm{~S}$ coated urea and methylene urea) was superior than using urea the fast release $\mathrm{N}$ fertilizer in enhancing all growth aspects, leaf pigments, nutrients $(\mathrm{N}, \mathrm{P}, \mathrm{K}, \& \mathrm{Mg})$, berry setting \%, yield and berry quality of the berries. Slow release fertilizer treatments effectively lowered both nitrate and nitrite in berry juice when compared with using urea. The best slow release fertilizer in this respect was methylene urea. Sulphur-coated urea occupied the last position in this respect. Using any slow release $\mathrm{N}$ fertilizer above $25 \%$ of the suitable $\mathrm{N}$ had no material effect on all the investigated characteristics.

Fertilizing Thompson Seedless grapevines with the suitable N (80 g. N/ yr.) as $25 \% \mathrm{~N}$ via methelen urea ( 89 g. N/ vine / yr.) is suggested to be beneficial for improving yield and quality of Thompson seedless grapevines.
\end{abstract}

Keywords: Slow release $\mathrm{N}$ fertilizers, Thompson seedless grapevines, yield and berries quality.

\section{INTRODUCTION}

During the last few years, newly controlled release fertilizers were developed to improve the efficiency of using nutrients, minimize the loss of nutrients via leaching and to reduce the pollution (Travis, 1971 and Nijjar, 1985). They are useful in supplying the trees with their requirements from various essential nutrients during all stages of plant development (Wang and Alva, 1996). In this respect, Travis (1971) stated that using slow release $\mathrm{N}$ fertilizers is responsible for controlling the uptake of $\mathrm{N}$ by the trees and at the same time supplying these trees with the available $\mathrm{N}$ at all stages of growth.

Previous studies was carried out, since Ahmed and El- Dawwey, (1992); Ahmed et al., (1993) and Mikkelesen et al., (1994). The results of Ragab et al., (1996); Akl et al., (1997); Ali- Mervet, (2000); Wassel et al., (2000); Kandil et al., (2010); Zhan et al., (2011); Abd El- Aziz, (2012); Ahmed and Abada, (2012) and Wei et al., (2012) emphasized the favourable effects of using slow release fertilizers as a replacement of fast ones on enhancing yield and fruit quality of fruit crops and another horticultural crops. Recently, (Alam, 2014) suggested that using slow release fertilizers was very effective in enhancing yield and berries quality of Superior seedless grapevines grown under Minia region conditions.

The goal of this study was examining the impact of replacing some slow release $\mathrm{N}$ fertilizers against those fast ones on fruiting of Thompson seedless grapevines.

\section{MATERIALS AND METHODS}

This study was carried out during 2014 and 2015 seasons on 48 10-years old Thompson seedless grapevine. The chosen vines were similar in growth as possible and they were planted in a sandy loam soil under surface irrigation system and spaced at $2 \times 2$ meters apart in a private vineyard located at West Samalout, Minia governorate. The vines were head pruned during the first week of Jan. during both seasons by leaving vine 72 eyes (10 long fruiting spurs $x$ six eyes plus six renewal spurs $\mathrm{x}$ two eyes). Soil analysis was done (Wilde et al., 1985) and the data are shown in table (1).

Table (1): Analysis of the tested soil

\begin{tabular}{|c|c|}
\hline Characters & Values \\
\hline Sand $\%$ & 56.66 \\
\hline Silty \% & 21.67 \\
\hline Clay $\%$ & 21.67 \\
\hline Texture & Sandy loam \\
\hline Organic matter $\%$ & 1.42 \\
\hline $\mathrm{pH}(1: 2.5$ extract $)$ & 7.75 \\
\hline EC $(1: 2.5$ extract $)\left(\operatorname{mmhos} / 1 \mathrm{~cm} / 25^{\circ} \mathrm{C}\right)$ & 1.11 \\
\hline $\mathrm{CaCO}_{3} \%$ & 1.92 \\
\hline Total N \% & 0.09 \\
\hline Available P ( ppm, Olsen) & 2.20 \\
\hline Available ( ppm, ammonium acetate) & 21.0 \\
\hline
\end{tabular}

The selected vines received the common horticultural practices that already applied in the vineyard except those dealing with the addition of slow and fast released fertilizers. 
This study included the following eight treatments:

1-Supplying the vines with N (80 g. / vine / yr.) through $100 \% \mathrm{~N}$ via urea ( $46.5 \%$ ) ( $172 \mathrm{~g}$. urea / vine/ yr.) .

2-Supplying the vines with $\mathrm{N}$ as $50 \% \mathrm{~N}$ via urea $(86 \mathrm{~g}$. urea / vine/ yr.).

3-Supplying the vines with $\mathrm{N}$ as $50 \% \mathrm{~N}$ via phosphourcoated urea $(37.11 \% \mathrm{~N})$ ( $108 \mathrm{~g}$. / vine / yr.).

4-Supplying the vines with $\mathrm{N}$ as $25 \% \mathrm{~N}$ via phosphourcoated urea ( $54 \mathrm{~g}$. / vine / yr.).

5-Supplying the vines with $\mathrm{N}$ as $50 \% \mathrm{~N}$ via sulphur coated urea $(41 \% \mathrm{~N})(98 \mathrm{~g}$. / vine / yr.).

6-Supplying the vines with $\mathrm{N}$ as $25 \% \mathrm{~N}$ via sulphur coated urea (49 g. / vine / yr.).

7-Supplying the vines with $\mathrm{N}$ as $50 \% \mathrm{~N}$ via methylene urea $(22.5 \% \mathrm{~N})$ ( $178 \mathrm{~g}$. / vine / yr.).

8-Supplying the vines with $\mathrm{N}$ as $25 \% \mathrm{~N}$ via methylene urea (89 g. / vine / yr.).

Each treatment was replicated three times, two vines per each replicate. All the selected vines (48 vines) were received $\mathrm{N}$ at fixed rate namely $80 \mathrm{~g}$. $\mathrm{N} /$ vine/ yr. (Ahmed and Abada, 2012). The fast release $\mathrm{N}$ fertilizer namely urea was added at three unequal batches $40 \%$ at growth start (first week of March ), $40 \%$ just after berry setting ( $3^{\text {rd }}$ week of May ) and $20 \%$ two week prior verasion stage ( $1^{\text {st }}$ week of June ). The three slow release fertilizers were added once at growth start $\left(1^{\text {st }}\right.$ week of March). They were added on drenches around the vines $(10 \times 10 \times 10 \mathrm{~cm}$. dimensions).

Experiment consists of eight treatments arranged as a Randomized complete block design (RCBD). Each treatment was replicated three times and each replicate included two vines.

The following parameters were measured to evaluate the tested treatments:

1-Vegetative growth aspects namely main shoot length (cm.) leaf area (cm. ${ }^{2}$ ) (Ahmed and Morsy, 1999), number of leaves per shoot, cane thickness (cm.), weight of removal one- year old wood (kg.) / vine and ripening coefficient (length of brownish wood / total length).

2-Leaf pigments namely chlorophylls a \& b, total chlorophylls and total carotenoids as mg. / $100 \mathrm{~g}$. F.W. (Von- Wettstein, 1957).

3-Leaf content of $\mathrm{N}, \mathrm{P}, \mathrm{K}$ and $\mathrm{Mg}$ in the petioles (from leaves opposite to the basal clusters) before verasion stage on dry weight basis (Summer, 1985 and Wilde et al., 1985).

4-Yield as well as percentage of berry setting expressed as number of clusters per vine and weight $(\mathrm{kg}$.$) as$ well as cluster weight (g.) and dimensions (width \& length $\mathrm{cm}$.).

5-Physical and chemical characteristics of the berries namely average berry weight (cm.), T.S.S. \%, reducing sugars $\%$, titratable acidity $\%$ (as tartaric acid / 100 ml. juice), T.S.S./ acid, total carotenoids (mg./ 100 g. F.W.) according to A.O.A.C. (2000) and both nitrate and nitrite (as ppm.) in the juice according to Ridnour - Lisa et al., (2000).

Statistical analysis was done using the procedure of Mead et al., (1993) and the treatment means were compared using new L.S.D. at 5\%.

\section{RESULTS AND DISCUSSION}

\section{1-Vegetative growth aspects:}

It is clear from Table (2) that supplying Thompson seedless grapevines with $\mathrm{N}(80 \mathrm{~g}$. N/ vine/ $\mathrm{yr}$.) as $50 \% \mathrm{~N}$ through any one of the three slow release fertilizers ( $\mathrm{P}$ or $\mathrm{S}$ coated urea and methylene urea) significantly stimulated main shoot length, leaf area, number of leaves/ shoot, cane thickness, wood pruning weight and wood ripening coefficient compared to using the fast release urea fertilizer. The best slow release fertilizers, in ascending order were P- coated urea, Scoated urea and methylene urea. Significant differences on these growth characters were observed among the four slow and fast release fertilizers. Increasing the levels of urea from 50 to $100 \% \mathrm{~N}$ had significant promotion on these growth characteristics. However, increasing the percentages of $\mathrm{N}$ from 25 to $50 \%$ applied via slow release fertilizers failed to show significant promotion on these growth traits. Using the suitable $\mathrm{N}$ (80 g. / N/ vine/ yr.) via the slow release fertilizer methylene urea at $50 \% \mathrm{~N}$ gave the maximum values of main shoot length $(116.6 \& 118.3 \mathrm{~cm}$.), leaf area $(90.6$ $\& 92.7 \%$ ), number of leaves/ shoot ( $31 \& 33$ ), cane thickness $(1.20 \& 1.28 \mathrm{~cm}$.), pruning wood weight $(3.3$ $\& 3.0 \mathrm{~kg}$.) and wood ripening coefficient (0.91 \& 0.92) during both seasons, respectively. The minimum values were recorded on the vines that received $\mathrm{N}$ as $25 \%$ via urea. These results were true during both seasons.

Table (2): Effect of using the three slow release fertilizers as a replacement of the soluble fertilizer urea on some growth aspects of Thompson seedless grapevines during 2014 \& 2015 seasons.

\begin{tabular}{|c|c|c|c|c|c|c|c|c|c|c|c|c|}
\hline \multirow{2}{*}{ Treatment } & \multicolumn{2}{|c|}{$\begin{array}{c}\text { Main shoot } \\
\text { length }(\mathrm{cm} .)\end{array}$} & \multicolumn{2}{|c|}{$\begin{array}{c}\text { Leaf area } \\
(\mathrm{cm} .)^{2}\end{array}$} & \multicolumn{2}{|c|}{$\begin{array}{c}\begin{array}{c}\text { No. of leaves / } \\
\text { shoot }\end{array} \\
\end{array}$} & \multicolumn{2}{|c|}{$\begin{array}{c}\text { Cane thickness } \\
(\mathrm{cm} .)\end{array}$} & \multicolumn{2}{|c|}{$\begin{array}{c}\text { Pruning weight } \\
\text { (kg./ vine) }\end{array}$} & \multicolumn{2}{|c|}{$\begin{array}{c}\text { Wood ripening } \\
\text { coefficient }\end{array}$} \\
\hline & 2014 & 2015 & 2014 & 2015 & 2014 & 2015 & 2014 & 2015 & 2014 & 2015 & 2014 & 2015 \\
\hline Urea via $100 \% \mathrm{~N}$ & 105.0 & 106.6 & 80.3 & 82.0 & 22.0 & 24.0 & 0.96 & 1.01 & 2.2 & 1.9 & 0.72 & 0.66 \\
\hline Urea via $50 \% \mathrm{~N}$ & 101.0 & 102.7 & 79.0 & 80.6 & 20.0 & 21.0 & 0.90 & 0.95 & 1.9 & 1.7 & 0.65 & 0.60 \\
\hline $\mathrm{P}$ - coated urea via $50 \% \mathrm{~N}$ & 108.7 & 110.3 & 83.0 & 84.7 & 25.0 & 27.0 & 1.01 & 1.06 & 2.7 & 2.3 & 0.79 & 0.71 \\
\hline $\mathrm{P}$ - coated urea via $25 \% \mathrm{~N}$ & 108.0 & 109.6 & 82.6 & & & & & & & & 77 & 0.70 \\
\hline S- coated urea via $50 \% \mathrm{~N}$ & 113.3 & 115.0 & 87.1 & 88.9 & 28.0 & 31.0 & 1.10 & 1.15 & 3.0 & 2.7 & 0.87 & 0.80 \\
\hline S- coated urea via $25 \% \mathrm{~N}$ & 112.9 & 114.6 & 86.9 & 88.5 & 27.0 & 30.0 & 1.09 & 1.14 & 2.9 & 2.6 & 0.86 & 0.79 \\
\hline Methylene urea via $50 \% \mathrm{~N}$ & 116.6 & 118.3 & 90.6 & 92.7 & 31.0 & 33.0 & 1.20 & 1.28 & 3.3 & 3.0 & .91 & 0.92 \\
\hline Methylene urea via $25 \% \mathrm{~N}$ & 116.0 & 117.6 & 90.0 & 92.0 & 30.0 & 32.0 & 1.19 & 1.27 & 3.0 & 2.9 & 0.90 & 0.86 \\
\hline New L.S.D. at 5\% & 1.2 & 1.3 & 1.0 & 0.9 & 2.0 & 2.0 & 0.04 & 0.04 & 0.2 & 0.2 & 0.05 & 0.05 \\
\hline
\end{tabular}




\section{2- Leaf chemical composition:}

Data from Tables ( $3 \& 4$ ) reveal that supplying the vines with $\mathrm{N}$ as 25 to $50 \%$ via the three slow release fertilizer namely $\mathrm{P}$ or S coated urea and methylene urea had significant promotion on all pigments (chlorophylls a \& b , total chlorophylls and total carotenoids) and nutrients $(\mathrm{N}, \mathrm{P}, \mathrm{K} \& \mathrm{Mg})$ in the leaves relative to the application of urea. The promotion was slightly associated with increasing percentages of $\mathrm{N}$ from 50 to $100 \%$ for urea, and from 25 to $50 \%$ for the three slow release fertilizers. This stimulation on these pigments and nutrients significantly was depended on using methylene urea, S- coated urea and P- coated urea , in descending order. The maximum values of chlorophyll a
(9.1 \& $9.2 \mathrm{mg} / 100$ g F.W.), chlorophyll b ( $3.5 \& 3.4$ $\mathrm{mg} / 100$ g F.W.), total chlorophylls (12.6 \& $12.6 \mathrm{mg} . /$ 100 g. F.W.), total carotenoids $(3.6 \& 3.5 \mathrm{mg} . / 100 \mathrm{~g}$. F.W.), N ( $2.10 \& 2.12 \%), \mathrm{P}(0.33 \& 0.17 \%), \mathrm{K}(1.41$ $\& 1.46 \%)$ and $\mathrm{Mg}(0.71 \& 0.75 \%)$ were recorded on the vines that received $\mathrm{N}$ as methylene urea at $50 \% \mathrm{~N}$. Increasing the levels of urea from 50 to $100 \% \mathrm{~N}$ caused a significant promotion on all pigments and $\mathrm{N} \%$ and a reduction on nutrients namely $\mathrm{P} \& \mathrm{~K} \& \mathrm{Mg}$ in the leaves. The minimum values of plant pigments and $\mathrm{N}$ were observed on the vines that supplied with urea at $50 \% \mathrm{~N}$. Using urea at $100 \% \mathrm{~N}$ gave the lowest values of $\mathrm{P}, \mathrm{K}$ and $\mathrm{Mg}$ in the leaves. Similar results were announced during 2014 \& 2015 seasons.

Table (3): Effect of using the three slow release fertilizers as a replacement of the soluble fertilizer urea on some leaf pigments (mg./ 100 g. F.W.) of Thompson seedless grapevines during 2014 \& 2015 seasons.

\begin{tabular}{|l|c|c|c|c|c|c|c|c|}
\hline \multirow{2}{*}{ Treatment } & \multicolumn{2}{c|}{$\begin{array}{c}\text { Chlorophyll a (mg./ } \\
\text { 100 g. F.W.) }\end{array}$} & \multicolumn{2}{c|}{$\begin{array}{c}\text { Chlorophyll b (mg./ } \\
\text { 100 g. F.W.) }\end{array}$} & $\begin{array}{c}\text { Total chlorophylls } \\
\text { (mg./ 100 g. F.W.) }\end{array}$ & $\begin{array}{c}\text { Total carotenoids } \\
\text { (mg./ 100 g. F.W.) }\end{array}$ \\
\cline { 2 - 10 } & $\mathbf{2 0 1 4}$ & $\mathbf{2 0 1 5}$ & $\mathbf{2 0 1 4}$ & $\mathbf{2 0 1 5}$ & $\mathbf{2 0 1 4}$ & $\mathbf{2 0 1 5}$ & $\mathbf{2 0 1 4}$ & $\mathbf{2 0 1 5}$ \\
\hline Urea via 100\% N & 6.6 & 7.0 & 2.1 & 2.0 & 8.7 & 9.0 & 2.0 & 1.9 \\
\hline Urea via 50\% N & 6.1 & 6.4 & 1.8 & 1.7 & 7.9 & 8.1 & 1.7 & 1.6 \\
\hline P- coated urea via 50 \% N & 7.4 & 7.7 & 2.5 & 2.4 & 9.9 & 10.1 & 2.5 & 2.4 \\
\hline P- coated urea via 25 \% N & 7.3 & 7.6 & 2.4 & 2.3 & 9.7 & 9.9 & 2.4 & 2.3 \\
\hline S- coated urea via 50 \% N & 8.2 & 8.3 & 3.0 & 2.9 & 11.2 & 11.2 & 3.0 & 2.9 \\
\hline S- coated urea via 25 \% N & 8.0 & 8.2 & 2.8 & 2.7 & 10.8 & 10.9 & 2.9 & 2.8 \\
\hline Methylene urea via 50 \% N & 9.1 & 9.2 & 3.5 & 3.4 & 12.6 & 12.6 & 3.6 & 3.5 \\
\hline Methylene urea via 25 \% N & 9.0 & 9.1 & 3.3 & 3.2 & 12.3 & 12.3 & 3.3 & 3.2 \\
\hline New L.S.D. at 5\% & 0.4 & 0.5 & 0.2 & 0.2 & 0.5 & 0.5 & 0.2 & 0.2 \\
\hline
\end{tabular}

Table (4): Effect of using the three slow release fertilizers as a replacement of the soluble fertilizer urea on the percentages of $\mathrm{N}, \mathrm{P}, \mathrm{K}$ and $\mathrm{Mg}$ in the leaves of Thompson seedless grapevines during 2014 \& 2015 seasons.

\begin{tabular}{|l|c|c|c|c|c|c|c|c|}
\hline \multirow{2}{*}{ Treatment } & \multicolumn{2}{|c|}{ Leaf N \% } & \multicolumn{2}{c|}{ Leaf P } & \multicolumn{2}{c|}{ Leaf K \% } & \multicolumn{2}{c|}{ Leaf Mg \% } \\
\cline { 2 - 9 } & $\mathbf{2 0 1 4}$ & $\mathbf{2 0 1 5}$ & $\mathbf{2 0 1 4}$ & $\mathbf{2 0 1 5}$ & $\mathbf{2 0 1 4}$ & $\mathbf{2 0 1 5}$ & $\mathbf{2 0 1 4}$ & $\mathbf{2 0 1 5}$ \\
\hline Urea via 100\% N & 1.74 & 1.78 & 0.13 & 0.11 & 1.09 & 1.14 & 0.54 & 0.57 \\
\hline Urea via 50\% N & 1.66 & 1.71 & 0.16 & 0.17 & 1.15 & 1.19 & 0.58 & 0.60 \\
\hline P- coated urea via 50 \% N & 1.82 & 1.85 & 0.37 & 0.36 & 1.22 & 1.27 & 0.61 & 0.65 \\
\hline P- coated urea via 25\% N & 1.81 & 1.84 & 0.36 & 0.35 & 1.21 & 1.26 & 0.60 & 0.64 \\
\hline S- coated urea via 50 \% N & 1.92 & 2.01 & 0.31 & 0.30 & 1.32 & 1.37 & 0.67 & 0.70 \\
\hline S- coated urea via 25 \% N & 1.90 & 1.95 & 0.30 & 0.29 & 1.31 & 1.36 & 0.66 & 0.69 \\
\hline Methylene urea via 50 \% N & 2.10 & 2.12 & 0.23 & 0.17 & 1.41 & 1.46 & 0.71 & 0.75 \\
\hline Methylene urea via 25\% N & 2.09 & 2.11 & 0.22 & 0.17 & 1.40 & 1.45 & 0.69 & 0.74 \\
\hline New L.S.D. at 5\% & 0.06 & 0.05 & 0.02 & 0.02 & 0.04 & 0.04 & 0.02 & 0.05 \\
\hline
\end{tabular}

\section{3- Yield and cluster aspects:}

Data in Table (5) clearly show that supplying the vines with $\mathrm{N}$ via the three slow release $\mathrm{N}$ fertilizers significantly was accompanied with improving yield expressed in number of clusters/ vine and weight $(\mathrm{kg}$. and cluster weight and dimensions (length \& width) comparing to supplying the vines with urea. Significant differences on these parameters were observed between the four slow and fast release fertilizers. Increasing urea levels from 50 to $100 \% \mathrm{~N}$ caused significant promotion on these criteria. However, insignificant promotion on these parameters were noticed with increasing the levels of the three slow release fertilizers from 25 to $50 \%$, N. Therefore, from economical point of view, it is suggested to use any slow release $\mathrm{N}$ fertilizer at $25 \% \mathrm{~N}$ ( 20 g. N/vine / yr.) .

The best results were obtained due to using methylene urea, S- coated urea and P- coated urea, in descending order. From economical point of view, it is preferable to supply the vines with $\mathrm{N}$ at $25 \% \mathrm{~N}$ via methylene urea. Under such promised treatment, yield per each vine reached 9.2 and $13.7 \mathrm{~kg}$. during both seasons, respectively. The vines reviewed $\mathrm{N}$ at $100 \%$ via urea (control treatment) produced 8.8 and $9.5 \mathrm{~kg}$. during both seasons, respectively. The percentage of increment on the yield due to using methylene urea at $25 \% \mathrm{~N}$ over the check treatment reached 4.5 and $44.2 \%$ during both seasons, respectively. These results were true during both seasons. 
Table (5): Effect of using the three slow release fertilizers as a replacement of the soluble fertilizer urea on the percentage of berry setting, yield and cluster characteristics of Thompson seedless grapevines during $2014 \& 2015$ seasons.

\begin{tabular}{|l|c|c|c|c|c|c|c|c|c|c|}
\hline \multirow{2}{*}{ Treatment } & \multicolumn{2}{c|}{$\begin{array}{c}\text { No. Of clusters / } \\
\text { vine }\end{array}$} & \multicolumn{2}{c|}{$\begin{array}{c}\text { Yield / vien } \\
\text { (kg.) }\end{array}$} & \multicolumn{2}{c|}{$\begin{array}{c}\text { Av. Cluster } \\
\text { weiht (g.) }\end{array}$} & \multicolumn{2}{c|}{$\begin{array}{c}\text { Av. cluster } \\
\text { length (cm.) }\end{array}$} & \multicolumn{2}{c|}{$\begin{array}{c}\text { Av. cluster } \\
\text { width (cm.) }\end{array}$} \\
\cline { 2 - 12 } & $\mathbf{2 0 1 4}$ & $\mathbf{2 0 1 5}$ & $\mathbf{2 0 1 4}$ & $\mathbf{2 0 1 5}$ & $\mathbf{2 0 1 4}$ & $\mathbf{2 0 1 5}$ & $\mathbf{2 0 1 4}$ & $\mathbf{2 0 1 5}$ & $\mathbf{2 0 1 4}$ & $\mathbf{2 0 1 5}$ \\
\hline 1- Urea via 100\% N & 24.0 & 26.0 & 8.8 & 9.5 & 366.0 & 364.5 & 13.5 & 14.0 & 8.5 & 8.9 \\
\hline 2-Urea via 50\% N & 23.0 & 24.0 & 8.3 & 8.6 & 360.0 & 358.5 & 13.0 & 13.6 & 8.0 & 8.4 \\
\hline 3-P- coated urea via 50 \% N & 24.0 & 30.0 & 8.9 & 11.1 & 371.0 & 369.0 & 14.1 & 14.6 & 9.2 & 9.7 \\
\hline 4- P- coated urea via 25 \% N & 24.0 & 28.0 & 8.9 & 10.3 & 369.0 & 368.0 & 14.0 & 14.5 & 9.0 & 9.6 \\
\hline 5- S- coated urea via 50 \% N & 24.0 & 32.0 & 9.1 & 12.1 & 378.0 & 377.0 & 15.0 & 15.7 & 10.1 & 10.9 \\
\hline 6- S- coated urea via 25 \% N & 24.0 & 31.0 & 9.0 & 11.7 & 377.0 & 376.0 & 14.9 & 15.5 & 9.9 & 10.8 \\
\hline 7- Methylene urea via 50 \% N & 24.0 & 35.0 & 9.2 & 13.5 & 384.0 & 385.0 & 16.1 & 16.3 & 11.0 & 11.6 \\
\hline 8- Methylene urea via 25 \% N & 24.0 & 34.0 & 9.2 & 13.7 & 383.0 & 384.0 & 16.0 & 16.2 & 10.9 & 11.5 \\
\hline New L.S.D. at 5\% & N.S & 2.0 & 0.2 & 0.4 & 4.1 & 3.9 & 0.4 & 0.4 & 0.3 & 0.3 \\
\hline
\end{tabular}

\section{4- Quality of the berries:}

From the data presented in Tables $(6 \& 7)$ it is clear that fertilizing Thompson seedless grapevines with any one of the three slow release fertilizers at $25 \%$ to $50 \% \mathrm{~N}$ caused a significant promotion on increasing berry weight, T.S.S. \% , reducing sugars \%, T.S.S./ acid and total carotenoids and decreasing titratable acidity, nitrite and nitrate in the juice relative to the use of urea the fast release $\mathrm{N}$ fertilizer at 50 to $100 \% \mathrm{~N}$. Increasing levels of the three slow release fertilizer from
25 to $50 \% \mathrm{~N}$ failed to show significant promotion on quality of the berries. The best slow release fertilizer was methylene urea followed by sulphur- coated urea and the slow release fertilizer P- coated urea ranked the last position in this respect., The best results economically point of view on quality of the berries were recorded on the vines that received methylene urea at $25 \% \mathrm{~N}$. These results were similar during the both seasons under the study.

Table (6): Effect of using the three slow release fertilizers as a replacement of the soluble fertilizer urea on some physical and chemical characteristics of the berries of Thompson seedless grapevines during 2014 \& 2015 seasons.

\begin{tabular}{|l|c|c|c|c|c|c|c|c|}
\hline \multirow{2}{*}{ Treatment } & \multicolumn{2}{|c|}{ Av. Berry weight (g.) } & \multicolumn{2}{c|}{ T.S.S. \% } & \multicolumn{2}{c|}{ Reducing sugars \% } & \multicolumn{2}{c|}{ Titratable acidity \% } \\
\cline { 2 - 9 } & $\mathbf{2 0 1 4}$ & $\mathbf{2 0 1 5}$ & $\mathbf{2 0 1 4}$ & $\mathbf{2 0 1 5}$ & $\mathbf{2 0 1 4}$ & $\mathbf{2 0 1 5}$ & $\mathbf{2 0 1 4}$ & $\mathbf{2 0 1 5}$ \\
\hline 1- Urea via 100\% N & 2.69 & 2.80 & 17.7 & 17.8 & 14.8 & 15.0 & 0.710 & 0.712 \\
\hline 2-Urea via 50\% N & 2.59 & 2.71 & 18.0 & 18.1 & 15.2 & 15.5 & 0.690 & 0.681 \\
\hline 3-P- coated urea via 50 \% N & 2.82 & 2.94 & 18.7 & 18.8 & 15.4 & 15.5 & 0.658 & 0.649 \\
\hline 4- P- coated urea via 25 \% N & 2.80 & 2.93 & 18.4 & 18.7 & 15.3 & 15.4 & 0.660 & 0.651 \\
\hline 5- S- coated urea via 50 \% N & 2.95 & 3.06 & 19.5 & 19.9 & 16.2 & 16.3 & 0.628 & 0.621 \\
\hline 6- S- coated urea via 25 \% N & 2.94 & 3.04 & 19.4 & 19.6 & 16.0 & 16.2 & 0.630 & 0.622 \\
\hline 7- Methylene urea via 50 \% N & 3.12 & 3.25 & 19.9 & 20.2 & 16.8 & 17.0 & 0.599 & 0.590 \\
\hline 8- Methylene urea via 25 \% N & 3.11 & 3.23 & 19.8 & 20.0 & 16.7 & 16.9 & 0.601 & 0.592 \\
\hline New L.S.D. at 5\% & 0.10 & 0.9 & 0.2 & 0.3 & 0.3 & 0.3 & 0.018 & 0.017 \\
\hline
\end{tabular}

Table (7): Effect of using the three slow release fertilizers as a replacement of the soluble fertilizer urea on some chemical characteristics of the berries of Thompson seedless grapevines during 2014 \& 2015 seasons.

\begin{tabular}{|l|c|c|c|c|c|c|c|c|}
\hline \multirow{2}{*}{ Treatment } & \multicolumn{2}{|c|}{$\begin{array}{c}\text { T.S.S./ } \\
\text { acid }\end{array}$} & \multicolumn{2}{c|}{$\begin{array}{c}\text { Total carotenoids in the } \\
\text { juice (mg./ 100 g. F.W.) }\end{array}$} & \multicolumn{2}{c|}{$\begin{array}{c}\text { Nitrate in the juice } \\
\text { (ppm.) }\end{array}$} & $\begin{array}{c}\text { Nitrite in the juice } \\
\text { (ppm.) }\end{array}$ \\
\cline { 2 - 9 } & $\mathbf{2 0 1 4}$ & $\mathbf{2 0 1 5}$ & $\mathbf{2 0 1 4}$ & $\mathbf{2 0 1 5}$ & $\mathbf{2 0 1 4}$ & $\mathbf{2 0 1 5}$ & $\mathbf{2 0 1 4}$ & $\mathbf{2 0 1 5}$ \\
\hline 1- Urea via 100\% N & 24.9 & 25.0 & 3.92 & 4.42 & 2.50 & 2.39 & 1.12 & 1.07 \\
\hline 2-Urea via 50\% N & 26.1 & 26.6 & 4.11 & 4.51 & 2.29 & 2.18 & 1.00 & 0.95 \\
\hline 3-P- coated urea via 50 \% N & 28.4 & 29.0 & 4.43 & 4.94 & 2.11 & 2.00 & 1.03 & 0.98 \\
\hline 4- P- coated urea via 25\% N & 27.9 & 28.7 & 4.41 & 4.90 & 2.10 & 1.99 & 1.00 & 0.95 \\
\hline 5- S- coated urea via 50 \% N & 31.3 & 32.0 & 4.58 & 5.12 & 1.72 & 1.61 & 0.79 & 0.74 \\
\hline 6- S- coated urea via 25 \% N & 30.8 & 31.5 & 4.55 & 5.10 & 1.71 & 1.60 & 0.77 & 0.72 \\
\hline 7- Methylene urea via 50 \% N & 33.2 & 34.5 & 5.04 & 5.22 & 1.12 & 1.00 & 0.61 & 0.55 \\
\hline 8- Methylene urea via 25 \% N & 32.9 & 33.8 & 5.00 & 5.19 & 1.11 & 0.90 & 0.60 & 0.54 \\
\hline New L.S.D. at 5\% & 0.7 & 0.6 & 0.08 & 0.09 & 0.10 & 0.17 & 0.11 & 0.09 \\
\hline
\end{tabular}




\section{DISCUSSION}

It is clear from our data that the previous beneficial effects of the three slow release fertilizers on fruiting of Thompson seedless grapevines might be attributed to their essential roles in minimizing the loss of nutrients via leaching as well as supplying of the vines with their requirements from nutrients at longer periods (Travis, 1971, Nijjar, 1985 and Wang and Alva, 1996). The effect of these slow release fertilizers on controlling and balancing the uptake of nutrients could give another interpretation (Wei et al., 2012).

These results are in harmony with those obtained by Ahmed and El- Dawwey, (1992); Ahmed et al., (1993) and Mikkelesen et al., (1994). The results of Ragab et al., (1996); Akl et al., (1997); Ali- Mervet (2000); Kandil et al., (2010); Zhan et al., (2011); Ahmed and Abada (2012) and Wei et al., (2012) came in the same conclusion.

\section{CONCLUSION}

According to the overall results, it could be concluded that amending Thompson seedless grapevines grown under Minia region conditions with the new slow release $\mathrm{N}$ fertilizer methylene urea at $20 \mathrm{~g}$. $\mathrm{N} /$ vine/ year (89 g./ vine / year) was sufficient for giving high yield and producing higher berries quality parameters.

\section{REFERENCES}

Ahmed, F.F. and Abada, M.A.M. (2012): Response of Thompson seedless grapevines to some slow release N, P and $\mathrm{K}$ fertilizers. Egypt J. Agric. Res. Vol. 90, No. (3):pp. 1-16.

Ahmed, F.F. and El- Dawwary, G.M. (1992): Did urea formaldehyde is really more effective on Red Roomy grapevines than urea the traditionally fast release fertilizer. Minia J. of Agric. Res. \& Develop. Vol. 12, No1: pp.20-39.

Ahmed, F.F. and Morsy, M.H. (1999): A new method for measuring leaf area in different fruit species. Minia, J. of Agric. Res., Develop. Vol. 19 pp. 97- 105.

Ahmed, F.F.; Nofal, M.A. and Assy K.G. (1993): Growth and nutrient uptake of Flame seedless grapevine seedlings in response to fertilization with some slow and fast release $\mathrm{N}$ fertilizers. Minia $1^{\text {st }}$ Conf. for Hort. Crops. pp. 1383-1394.

Akl, A.M.; Ahmed, F.F.; El- Morsy, F.M. and Ragab, M.A. (1997): Behaviour of Red Roomy grapevines in response to application of ureaformaldehyde, sulphur and some iron compounds. Proc. of the $1^{\text {st }}$ Sc. Conf. of Agric. Sci. Fac. of Agric. Assiut Univ. (1): pp106-118.

Alam, H.M.M. (2014): Productive capacity of Superior seedless grapevines in relation to application of some slow release fertilizers, Effective microorganisms and humic acid. $\mathrm{Ph}$. D. Thesis Fac. of Agric. Minia Univ. Egypt.
Ali - Mervet, A. (2000): Response of Flame seedless grapevines to slow release nitrogen fertilizers. Minia J. of Agric. Res. \& Develop. 20, No. (2):pp. 239-255.

Association of Official Agricultural Chemists (2000): Official Methods of Analysis (A.O.A.C), $12^{\text {th }}$ Ed., Benjamin Franklin Station, Washington D.Q, U.S.A. pp. 490-510.

Kandil, E.A.; Fawzi, M.I.F. and Shahin, M.F.M. (2010): The effect of some slow release nitrogen fertilizers on growth, nutrient status and fruiting of Mit. Ghamr Peach trees. J. Amer. Sci. 6, No. (12): pp. 195-201.

Mead, R.; Currnow, R. N. and Harted, A. M. (1993): Statistical Methods in Agricultural Biology. $2^{\text {nd }}$ Ed. Chapman \& Hall, London. pp. $50-70$.

Mikkelesen, L.R..; Williams, H.M. and Behel, A.D. (1994): Nitrogen leaching and plant uptake from controlled release fertilizers . Fert. Res., 37: pp. 43-50.

Nijjar, S. (1985): Nutrition of Fruit Trees. Kalyane publisher, New Delhi pp. 10- 70.

Ragab, M.A.; Ahmed, F.F. and El- Dawwey, G.M. (1996): Effect of rock phosphate and urea formaldehyde as slow release fertilizers on Red Roomy grapevines (Vitis vinifera L.) . Egypt Hort. Suez Canal. (2) pp. 224-2230.

Ridnour-Lisa, A.; Sim- Julia, E.; Michael, A.; David, A.; Sean, M.; Garry, R. and Douglas, R.(2000): A spectrophotometric Method for the Direct Detection and Quantitation of Nitric Oxide, Nitrite and Nitrate in Cell culture Media. Analytical Biochemistry, Vol.281:223-229.

Summer, M.E. (1985): Diagnosis and Recommendation Integrated system (DRIS) as a guide to orchard fertilization. Hort. Abst. 55, No.(8): p. 7502.

Travis, P.H. (1971): Controlled release fertilizers. Fertilizer New 5, 6 : pp. 42-48.

Von- Wettstein, D. V. C. (1957): Clatale and der Sumbmikro Skopisne Formwechsel de Plastids. Experimental Cell Research, pp. 12 - 427.

Wang, F.L. and Alva. A.K. (1996): Leaching of nitrogen from slow release urea sources on sandy soil . Soil. Sci. Am. J. 6 : pp. 1455-1455.

Wei , J.L. ; Cui, R.Z.; Zhang, Y.F.; Yang, G.; Yu, S.F. and Li, C.M. (2012): Effect of different applications amount of controlled release fertilizer on grape. Northern Hort. pp. 20 - 55.

Wilde, S.' A.; Corey, R. B.; Layer, J. G. and Voigt, G. K. (1985): Soils and Plant Analysis for Tree Culture. Oxford and IBH publishing Co., New Delhi, India.

Zhan, S.; Chu, G. and Xiao, L. (2011): Effects of Bag controlled slow release fertilizer on the yield and quality of Crimson seedless. J. of North West Forestry Univ. pp. 6:19. 


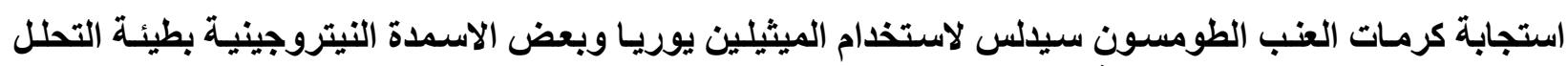


محمود محمد رفاعى لمعيماد محمد اليوريا المعمل المركزى للزراعة اعضى العضوية ـ مركز البحوث الزراعيةـ الجيزةـ مصر.

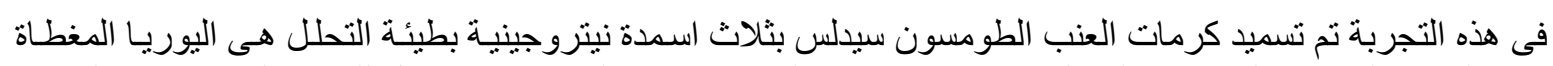

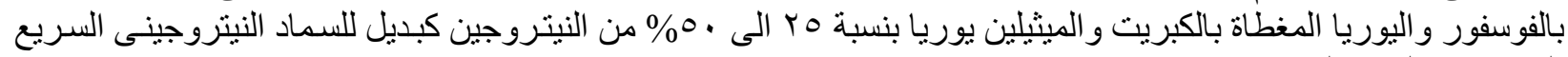
الذوبان فى الماء (اليوريا). ولقد أظهرت النتاءئج تفوق استخدام الى سماد من الاسمدة النيتروجينية البطيئة التحلل الثثلاثه (اليوريـا المغطاة بالفوسفور

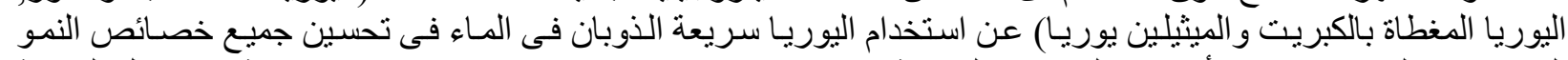





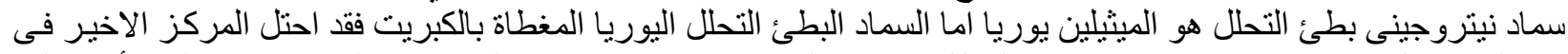

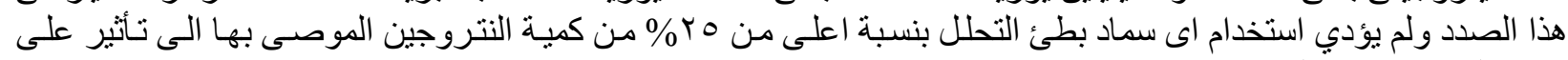

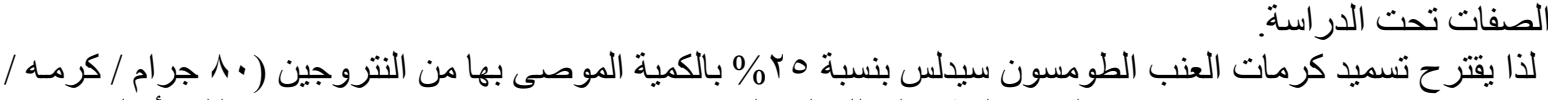

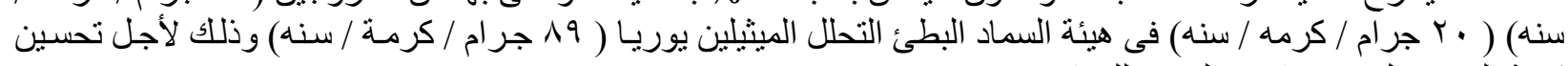


الكلمات الدالة: الاسمدة النتروجينية بطيئة التحلل - العنب الطومسون سيدلسـ كمية المحصولـ خصائص الجودة للحبات. 